\title{
Dilution-Extrapolation Hydrometer Method for Easy Determination of API Gravity of Heavily Weathered Hydrocarbons in Petroleum Contaminated Soil
}

\author{
Carlos M. Morales-Bautista ${ }^{1}$, Randy H. Adams ${ }^{1}$, Francisco Guzmán-Osorio ${ }^{1} \&$ Deysi Marín-García ${ }^{1}$ \\ ${ }^{1}$ División Académica de Ciencias Biológicas (DACBiol.), Universidad Juárez Autónoma de Tabasco, Villahermosa, \\ Tabasco, Mexico \\ Correspondence: Randy H. Adams, División Académica de Ciencias Biológicas, Universidad Juárez Autónoma \\ de Tabasco (UJAT), Km 0.5 Carr. VHSA-Cárdenas, Villahermosa, Tabasco, CP 86102, Mexico. Tel: \\ 52-993-330-1244. E-mail: drrandocan@hotmail.com
}

Received: February 21, 2013 Accepted: March 11, 2013 Online Published: March 30, 2013

doi:10.5539/eer.v3n1p115

URL: http://dx.doi.org/10.5539/eer.v3n1p115

\begin{abstract}
When crude petroleum is spilled onto soil, the oil's properties have a large influence on the toxicity to soil organisms, the biodegradability of the oil, and potential for long term fertility problems in the soil. Furthermore, these properties of environmental concern are related to the crude's density, commonly measured as API gravity. Currently, methods do not exist to determine the ${ }^{\circ} \mathrm{API}$ of crude oil in contaminated soil. In this study a novel method is presented for the determination of API gravity in small volumes $(<10 \mathrm{ml})$ of heavy and extra-heavy petroleum from contaminated soil. Is uses an economical and readily available solvent (diesel + automotive lubricating oil) in a procedure based on the conventional hydrometer method, plus dilution-extrapolation techniques. It was validated with crude petroleum in the 27.1-15.0 ${ }^{\circ} \mathrm{API}$ range, obtaining an excellent correlation with the conventional method $(\mathrm{R}=0.996)$ and an error of less than $0.4 \%$ based on specific gravity. Potential applications of this method are discussed for petroleum contaminated soil.
\end{abstract}

Keywords: analytical, ${ }^{\circ}$ API, biodegradation, contamination, soil fertility, specific gravity

\section{Introduction}

In several parts of the world, ecosystem pollution has been associated with crude oil spills, usually caused by pipeline breakage, or improper extraction and transport processes (Arife et al., 2005; Bakhtiari et al., 2009; Osuji \& Ezebuiro, 2006; Infante, 2001; Sakari et al., 2008; Sakari et al., 2010; Zakaria et al., 2002). Some physical and chemical properties of crude oil can cause deleterious effects in living beings (Adams et al., 2006; Eisman et al., 1991), and lower soil fertility (Adams et al., 2008; Litvina et al., 2003; Zalik et al., 2010). In the environmental area, the concentration of petroleum hydrocarbons in contaminated soil is usually determined using gravimetric extraction methods. However, these methods generally are not used to determine the properties of the oil in the soil.

None-the-less, petroleum engineers have known for decades that many properties of crude petroleum can be correlated to a simple parameter - the oil's density, commonly measured as API gravity. Also called API density or API degrees ( ${ }^{\circ} \mathrm{API}$ ), it is directly related to the specific gravity (density) of the oil. This parameter has been used to estimate valuable properties of this natural resource such as the quantity of easily recovered gasolines and middle distillates during refinery processes, residual content, sulphur, asphaltenes, and viscosity (Pemex Refinación, 2000; Udoetok \& Osuji, 2008). Likewise, on a regional basis, the fractional content of aliphatic, aromatic, and polar compounds have been related to API density.

Some of these properties, such as asphaltene and polar content are also related to environmentally important properties of crude oil, such as the biodegradability of petroleum in soil (McMillen et al., 2002), and negative impacts to soil fertility due to changes in important physical-chemical properties of the soil (Litvina et al., 2003; Adams et al., 2008). In addition, the toxicity of petroleum has been related to low molecular weight hydrocarbons, more common in low density (high ${ }^{\circ} \mathrm{API}$ ) petroleum (Eisman et al., 1991; Edwards et al., 1995). Thus, it can be very useful to know the ${ }^{\circ} \mathrm{API}$ of the oil in the soil at contaminated sites. For sites which have been recently contaminated, and in which the ${ }^{\circ} \mathrm{API}$ of the spilled oil is known, this information can be used to evaluate 
potential biodegradation, toxicity, and possible long term fertility problems in the soil. However, in older spills, where the oil has been transformed due to biodegradation and weathering, it would be very helpful to determine the API gravity of the existing oil in the soil (which will be different from that of the spilled oil).

Several methods can be used to determine API gravity (ASTM, 2002, 2006, 2008; Pemex Refinación, 2000). The ASTM D6822-02 thermo-hydrometer method (revised 2008) is among the most frequently used for the precise determination of API gravity in crude petroleum and petroleum products. The density is corrected to a reference temperature $\left(60^{\circ} \mathrm{F}=15.6^{\circ} \mathrm{C}\right)$ using standardized tables. This method is practical when the oil is fluid at room temperature and when relatively large volumes $(\sim 0.5 \mathrm{~L})$ are available. For extra-heavy crude oil and heavy fractions of refined oil (which are not fluid at room temperature), API gravity is usually determined using specialized equipment - a Gay-Lussac pycnometer (ASTM method D369-84, revised 2002). In this method, a small amount ( 10-25 ml) of oil is heated with constant mixing until fluid, and then poured into the pycnometer. As it cools, the volume is recorded at different temperatures. The density vs. temperature curve is plotted, and by applying the law of constant mass, and extrapolating to the reference temperature $\left(60^{\circ} \mathrm{F}\right)$, the density $\left({ }^{\circ} \mathrm{API}\right)$ is thus determined. This method encounters some difficulties when very heavy, viscous hydrocarbons are used, in that it is necessary to increase the temperature to high levels $\left(>150^{\circ} \mathrm{C}\right)$ and some of the hydrocarbons in the mixture may be evaporated or charred in the process. Also, the measurement of small changes in volume in very viscous mixtures is problematical and frequently imprecise.

However, these methods, by either hydrometer or pycnometer, are not practical for the determination of ${ }^{\circ} \mathrm{API}$ in residual concentrations in contaminated soil. In such conditions, the hydrocarbons are typically very weathered, dense, and found in relatively small concentrations $(<0.1-1 \%)$. Under these circumstances, it is very difficult and unpractical to try to extract sufficient oil from the soil to run a determination by the standard hydrometer method (which requires $\sim 0.5 \mathrm{~L}$ of oil). The pycnometer method requires less oil, but still has problems with precise quantification due to problems previously mentioned.

In this study, a modified, more practical, method was developed and validated. This method uses a low cost, easily available solvent (diesel+lubricating oil) in a dilution-extrapolation procedure to determine ${ }^{\circ} \mathrm{API}$ in small volumes $(<10 \mathrm{ml})$ of heavy and extra-heavy petroleum, such as that typically found as a residual fraction in an oil spill after a prolonged time period or following remediation activities.

\section{Experimental Work}

\subsection{Determination of API Gravity}

All of the API gravity determinations were made using a modification of the ASTM D6822-02 method (revised $2008)$, with three repetitions $(n=3)$. Crude petroleum with API gravities of $15.03,20.15$, and $27.11^{\circ} \mathrm{API}$ were used in this study. The medium crude $\left(27.11^{\circ} \mathrm{API}\right)$ was obtained from a tank storage facility in Comalcalco, Tabasco, (Mexico), and the heavier crude (15.03 $\left.{ }^{\circ} \mathrm{API}\right)$ was obtained from an out-of-service sulphur well in the Texistepec Mining Unit (Unidad Minera Texistepec, Texistepec, Veracruz). From these two sources, the third API gravity oil $\left(20.15^{\circ} \mathrm{API}\right)$ was obtained by combining and mixing in roughly equal quantities.

A mixture of automotive diesel (PEMEX) and multigrade lubricating oil API SL SAE 20W-50 (Bardahl, Mexico, D.F.) was used as solvent. The de-sulphurized automotive diesel (ID No. UN1202, guide 13, $35^{\circ} \mathrm{API}$; Pemex Refinación, 2000) was weathered at ambient temperature $\left(\sim 30^{\circ} \mathrm{C}\right)$ until enough of the lighter components had evaporated to have a relatively constant API gravity $\left(\sim 36^{\circ} \mathrm{API}\right)$, as measured using an integrated hydrometer with thermometer (ASTM, 2008), calibrated according to an ASTM 54HL standard, with a range of $29-41^{\circ} \mathrm{API}$ (Figure 1). Subsequently, this weathered diesel was mixed with the lubricant in proportions of approximately 1:1 $(\mathrm{w} / \mathrm{w})$ to prepare the solvent. Four hundred and fifty millilitres of this solvent were added to a $500 \mathrm{ml}$ graduated cylinder. In this same vessel, crude petroleum was slowly added and mixed using a glass rod until a final concentration of $0.5 \%(\mathrm{w} / \mathrm{w})$ was obtained. Once complete homogenization was achieved, ${ }^{\circ} \mathrm{API}$ was determined with the hydrometer and the reading was corrected for a density a $60^{\circ} \mathrm{F}\left(15.6^{\circ} \mathrm{C}\right)$. In the same cylinder, more petroleum was slowly added and mixed in, with increments of approximately $0.5 \%(\mathrm{w} / \mathrm{w})$, making readings with the hydrometer between additions. Increments up to only $2 \%$ were used for the heavy crude. For the medium crude, and crude oil mixture, increments up to $11 \%$ were used. 


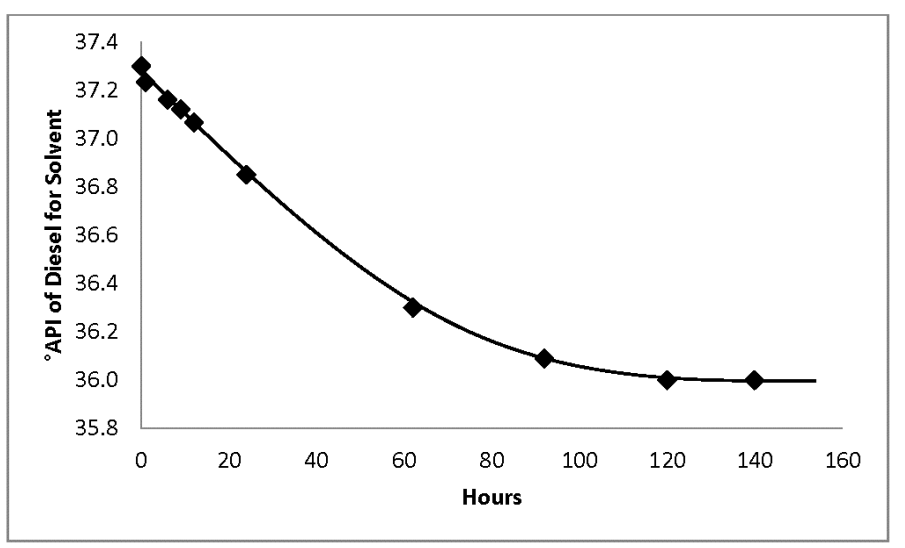

Figure 1. API gravity stabilization of the diesel used for solvent preparation

\subsection{Calculations, Correlations and Statistical Comparisons}

Based on the mass balance, the following equation was used:

$$
\left(\% W_{H C} \cdot{ }^{o} A P I_{H C}\right)+\left(\% W_{\text {Solv }} \cdot{ }^{o} A P I_{\text {Solv }}\right)=\left(\% W_{\text {Mix }} \cdot{ }^{o} A P I_{M i x}\right)
$$

Where:

$\% W_{H C}=$ weight percent of hydrocarbon in mixture,

${ }^{\circ} A P I_{H C}=$ API gravity of hydrocarbon (in this case, crude oil),

$\% W_{\text {Solv }}=$ weight percent of solvent (in this case, diesel + lube oil),

${ }^{\circ} A P I_{\text {Solv }}=$ API gravity of solvent,

$\% W_{\text {Mix }}=$ weight percent of mixture (crude oil + solvent),

${ }^{\circ} A P I_{M i x}=$ API gravity of mixture (crude oil + solvent).

Considering that: the $\% W_{H C}$ represents the quantity of hydrocarbon (crude oil) mass added, that the $\% W_{M i x}$ is constant $(100 \%)$, and the ${ }^{\circ} \mathrm{API}$ of the solvent (diesel + lube oil) is known (or measured), the above equation can be rearranged to obtain a single dependent variable:

$$
{ }^{\circ} A P I_{H C}=\left[\left(100 \% \cdot{ }^{\circ} A P I_{H C}\right)-\left(\% W_{\text {Solv }} \cdot{ }^{o} A P I_{S o l v}\right)\right] /\left[\% W_{H C}\right]
$$

To obtain more precision, linear regressions were performed on the ${ }^{\circ} \mathrm{API}$ vs. percent weight data to obtain correlation coefficients and regression functions. These functions were then extrapolated to $100 \%$ crude oil to calculate the API gravity of the (undiluted) crude oil. Direct hydrometer readings on the three crude oils (observed ${ }^{\circ}$ API values) were compared to the calculated values. The correlation between these values was evaluated by linear regression analysis. Additionally, the calculated vs. observed values were compared statistically using Statgraphics ${ }^{\circledR}$ ver. 5.1.

\section{Results and Discussion}

\subsection{Comparison of Dilution-Extrapolation Hydrometer Method to Standard Hydrometer Method}

The results of the determinations using the dilution-extrapolation method are shown in Figures 2-4, in which the API gravity has already been normalized to $60^{\circ} \mathrm{F}$. In these figures the relationship between percent crude petroleum $\left(\% \mathrm{~W}_{\mathrm{HC}}\right)$ in the solvent (diesel + lubricating oil) is graphed against ${ }^{\circ} \mathrm{API}$ (of the mix of crude oil + solvent) for the three crude petroleums used $\left(15.03,20.15\right.$ and $\left.27.11^{\circ} \mathrm{API}\right)$. Linear regressions are observed with correlations of $|\mathrm{R}|>0.98$, showing less uncertainty in the heavier crudes $(|\mathrm{R}|=0.994)$ than in the medium crude $(|\mathrm{R}|>0.983)$. This is due to the inverse relationship between API gravity and specific gravity. With the lighter petroleum, more is needed to be able to observe a notable difference on the hydrometer, thus the smaller difference in the API gravity measurement in the lighter (less dense) petroleum, and the lower precision obtained by visual measurements of smaller differences. For this reason is was necessary to add more petroleum to the solvent, up to a final concentration of about $11 \%(\mathrm{w} / \mathrm{w})$, versus only about $2 \%$ for the heavy crude. However, this may be of little practical importance, at least in most older spills, due to the fact that the great majority of soils contaminated with petroleum in these environments have predominately weathered hydrocarbons, rich in heavy and extra-heavy oil (Adams \& Morales, 2008; Udoetok \& Osuji, 2008; Litvina et al., 2003). With this 
method it is possible to determine the API gravity of oil in contaminated soil using less sample, even when the concentration of hydrocarbons in the soil is relatively low $(<1 \%)$, and when the soil is contaminated with heavy and extra-heavy oils.

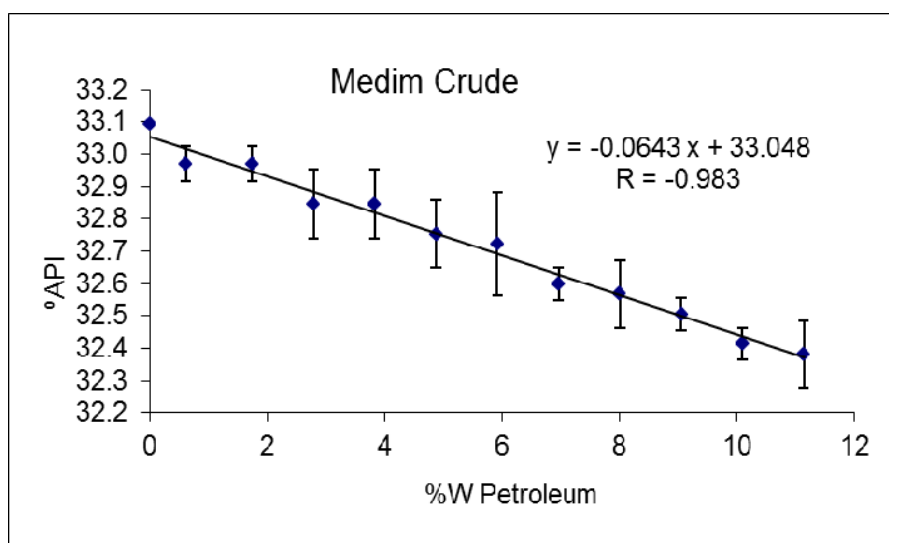

Figure 2. Relationship between ${ }^{\circ} \mathrm{API}$ and weight percent of medium crude petroleum Note: Error bars represent one standard deviation.

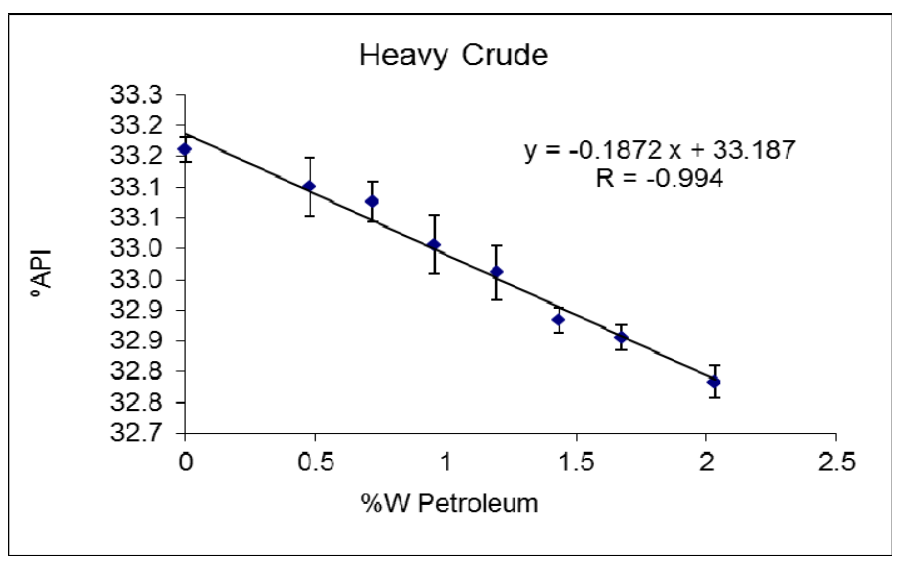

Figure 3. Relationship between ${ }^{\circ} \mathrm{API}$ and weight percent of heavy crude petroleum Note: Error bars represent one standard deviation.

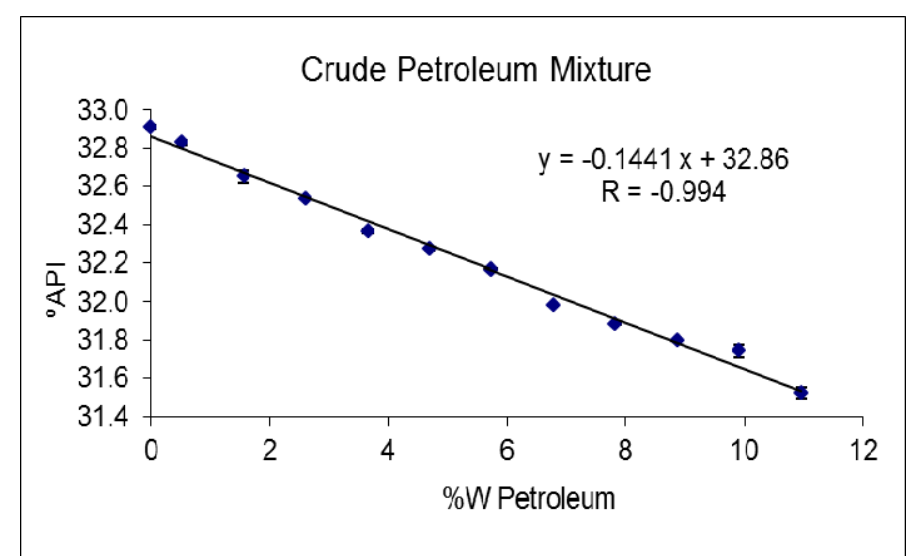

Figure 4. Relationship between ${ }^{\circ}$ API and weight percent of crude petroleum mixture Note: Error bars represent one standard deviation. 
The correlation between the calculated values obtained by this novel method and the conventional method is shown in Figure 5. As seen in this figure, there is an excellent correspondence $(\mathrm{R}=0.9996)$ with the function constrained to pass through zero, and with a slope of nearly 1 (1.0002). In this figure, the error bars are so small as to be nearly imperceptible. The difference between these methods, based on specific gravity, was less than $0.4 \%$. The statistical comparison of the direct method vs. the dilution-extrapolation method showed no significant difference for all three oils (no overlap in Standard Deviation at a 99\% Confidence Limit, Figures 6-8). The slight differences that were observed, were much less in the heavy crude in comparison with the medium crude or crude oil mixture. A Kruskal-Wallis test of the data indicated a p-value of 0.0369 with no significant differences at a $99 \%$ confidence level.

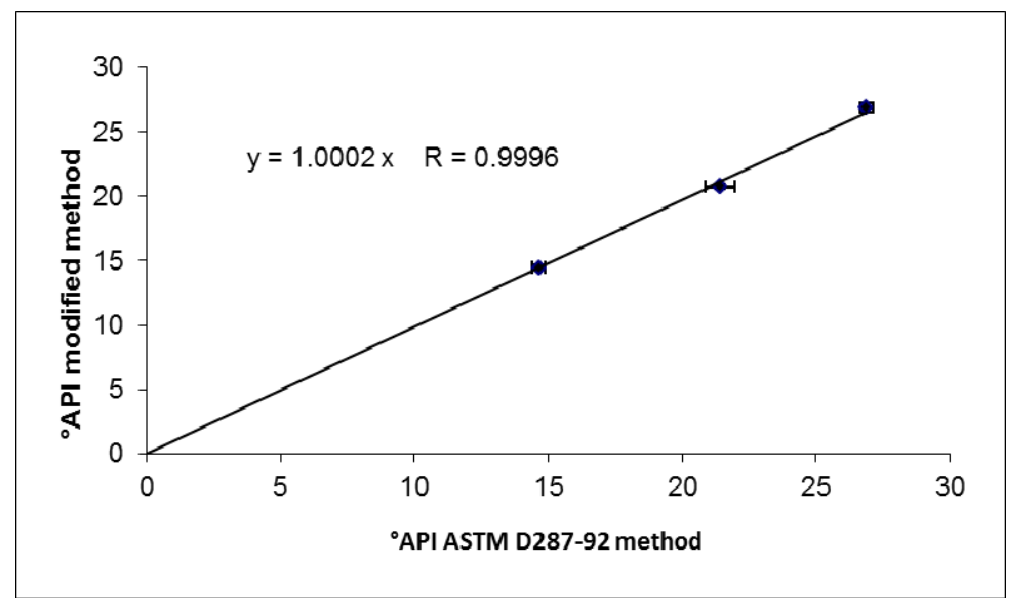

Figure 5. Correlation between dilution-extrapolation method and direct measurement with hydrometer Note: Error bars represent one standard deviation (nearly imperceptible).

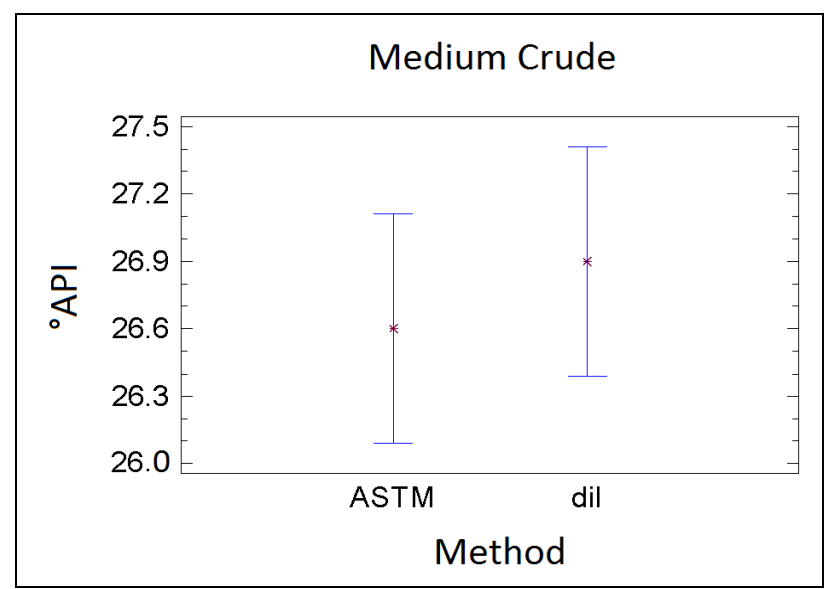

Figure 6. Statistical comparison between the ASTM method vs dilution extrapolation (medium crude petroleum) Note: Error bars represent 99\% confidence intervals (mean difference). 


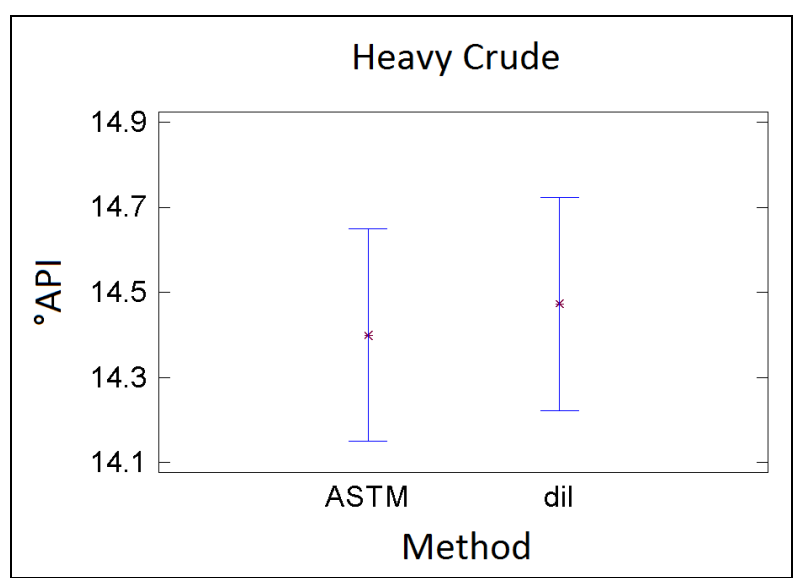

Figure 7. Statistical comparison between the ASTM method vs dilution extrapolation (heavy crude petroleum) Note: Error bars represent 99\% confidence intervals (mean difference).

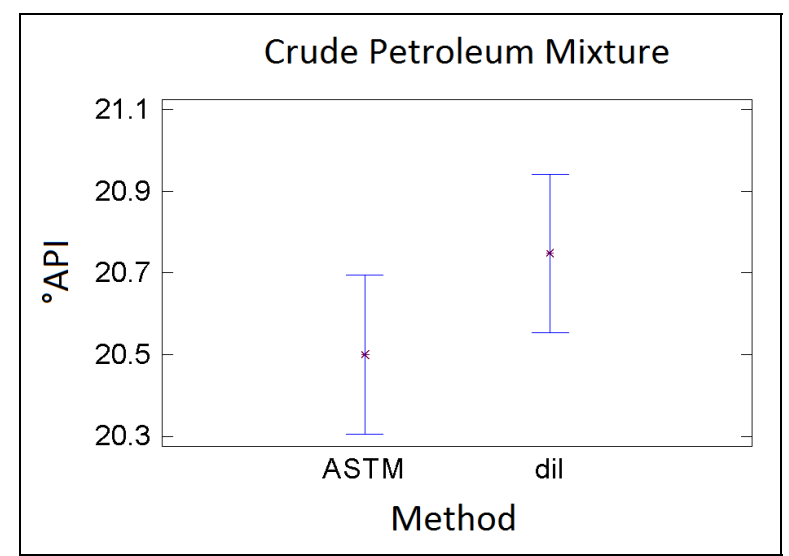

Figure 8. Statistical comparison between the ASTM method vs dilution extrapolation (crude petroleum mixture)

Note: Error bars represent $99 \%$ confidence intervals (mean difference).

\subsection{Utility of Novel Method for Characterization of Petroleum Contaminated Soils}

The determination of ${ }^{\circ} \mathrm{API}$ of weathered oil in contaminated soil can be very practical for the evaluation of many properties of environmental concern. For example, it is well known that the more viscous and weathered the oil is (lower ${ }^{\circ} \mathrm{API}$ ), it is much more difficult to biodegrade. McMillen et al. (2002), have shown that the bioremediation endpoint is directly proportional to the ${ }^{\circ} \mathrm{API}$ of the oil spilled $(\mathrm{R}=0.978)$, and crudes with a value of about $30^{\circ} \mathrm{API}$ and higher are readily biodegradable, whereas oils with ${ }^{\circ} \mathrm{API}$ values of 20 or less are very difficult and slow to biodegrade. Likewise, the presence of more polar functional groups in the residual oil, may enhance the formation of thin layers of oil on the surfaces of soil particles, and thereby cause water repellency (Litvina et al., 2003). This process may also lead to reduced field capacity, and compaction in the soil (Adams et al., 2008, Trujillo-Narcia et al., 2012). Such polar groups are more common in weathered (low ${ }^{\circ} \mathrm{API}$ ) oil, which has a higher proportion of polar compounds and asphaltenes (McMillen et al., 2002), and much greater viscosity (Ancheyta et al. 2011). Thus, in contaminated soil containing a residual oil with lower ${ }^{\circ}$ API values, there may be a much greater probability of long term fertility problems.

As a simple test of the utility of determining the ${ }^{\circ}$ API of oil in contaminated soil for environmental purposes, we evaluated the correlation between ${ }^{\circ} \mathrm{API}$ and two properties of environmental importance (viscosity and $\mathrm{S}$ content). Using existing data, we evaluated 10 crudes from South East Asia, from oil fields in central Sumatra, the Gulf of Thailand, the Natuna Sea, and the South China Sea, with a range of $20-60^{\circ}$ API, (Chevron Corporation, 2011; Table 1 and Figure 9). In this data set, the sulphur content (and therefore the relative proportion of polar 
functional groups in the oil, and thus, potential for soil fertility problems) was highly correlated to ${ }^{\circ} \mathrm{API}$ $((|\mathrm{R}|=0.969$, Figure 10a). Likewise, the viscosity (and therefore biodegradability), was also logarithmically related to ${ }^{\circ} \mathrm{API}$ with a high correlation $(|\mathrm{R}|=0.955$, Figure $10 \mathrm{~b})$.

Table 1. Properties of some crude oils from SE Asia

\begin{tabular}{llrrc}
\hline Crude Oil & Area & ${ }^{\circ}$ API & Viscosity $\left(\right.$ cSt at $\left.50^{\circ} \mathrm{C}\right)$ & $\mathbf{W t} \% \mathbf{~ S}$ \\
\hline Duri & Central Sumatra & 20.29 & 205.40 & 0.21 \\
Minas & Central Sumatra & 33.94 & 9.72 & 0.09 \\
Sembilang & Natuna Sea & 35.20 & 11.59 & 0.05 \\
Pattani & Gulf of Thailand & 38.11 & 3.78 & 0.06 \\
Nanhai Light & S China Sea & 39.50 & 4.03 & 0.06
\end{tabular}

(Hong Kong area)

\begin{tabular}{lllll} 
Tantawan & Gulf of Thailand & 41.64 & 2.90 & 0.05 \\
Benchamas & Gulf of Thailand & 41.82 & 4.17 & 0.04 \\
Belida & Natuna Sea & 46.60 & 1.99 & 0.02 \\
Belanak & Natuna Sea & 53.17 & 1.40 & 0.01 \\
Erawan & Gulf of Thailand & 58.90 & 0.60 & 0.01 \\
\hline
\end{tabular}

Chevron Corporation (2011). Chevron Crude Oil Marketing/Far Eastern Crudes - Whole Crude Properties. Retrieved from http://crudemarketing.chevron.com/crude/far_eastern

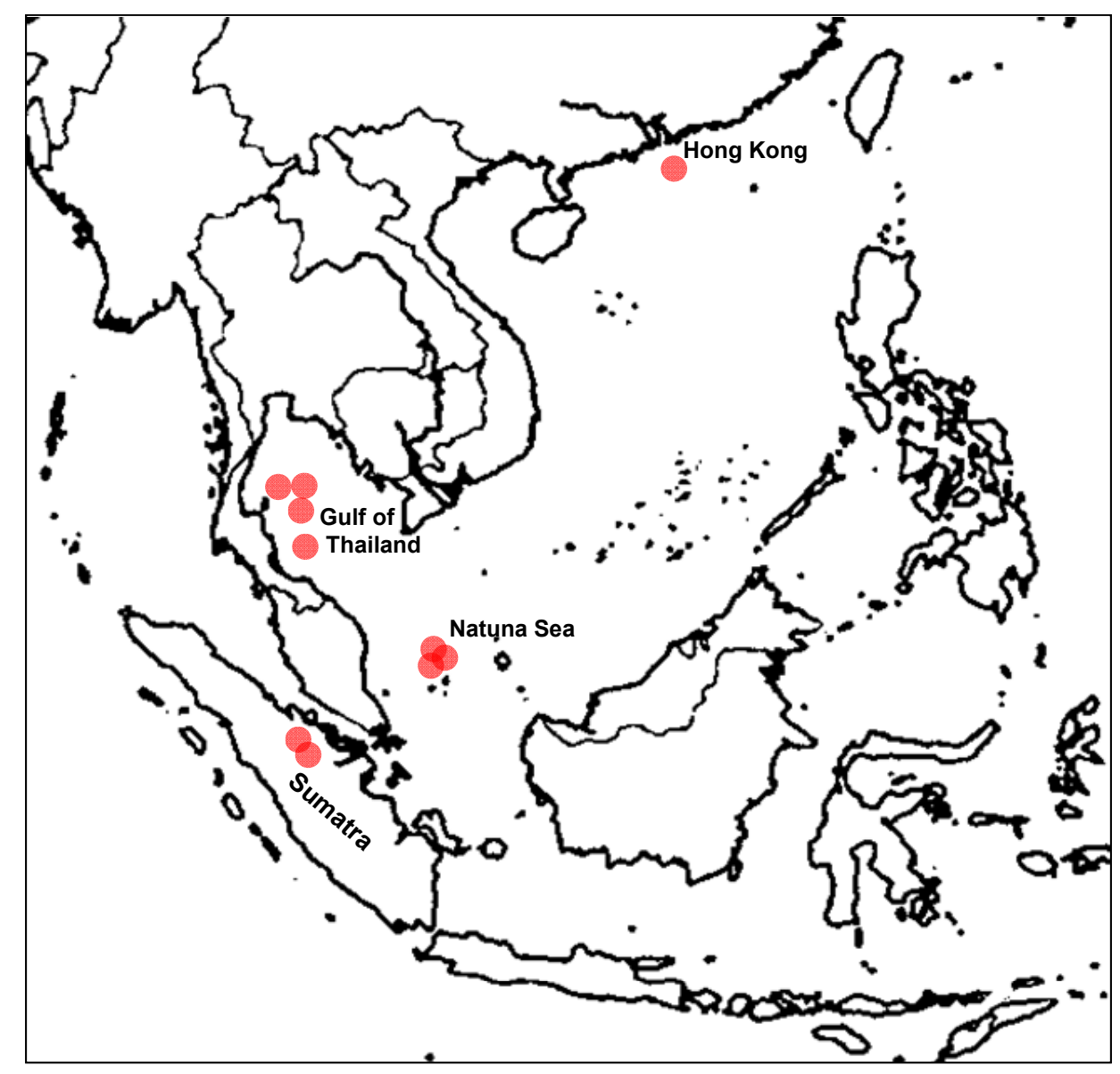

Figure 9. Approximate locations of SE Asian oil fields used in ${ }^{\circ}$ API utility evaluation 

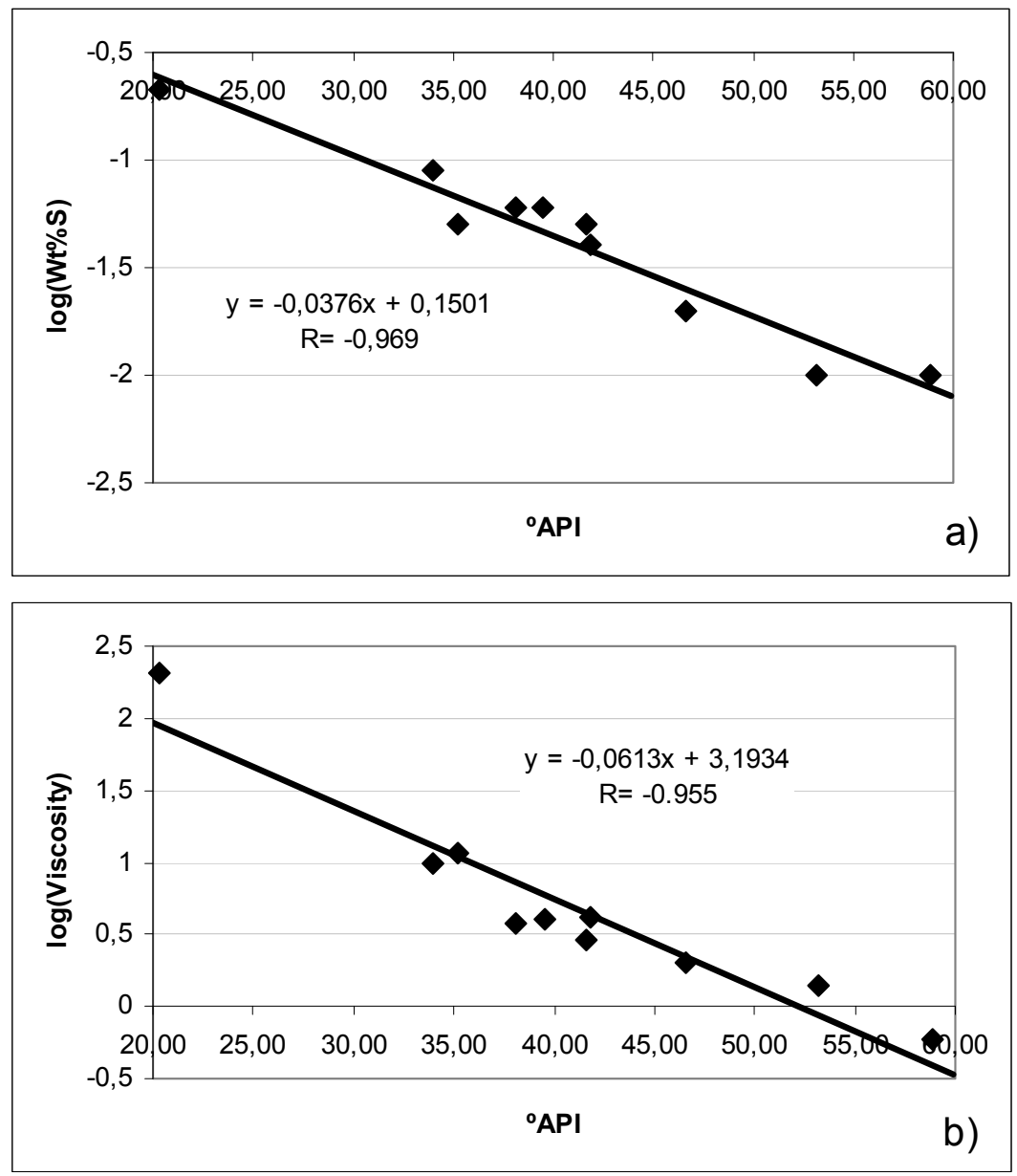

Figure 10. Correlation between ${ }^{\circ} \mathrm{API}$ and sulphur content (a)), and viscosity (b)) of crude oils from SE Asia Note: Sulphur content as weight percent; viscosity at $50^{\circ} \mathrm{C}$ in cSt. Correlations are logarithmic.

These correlations indicate that the biodegradability and potential long term fertility problems of soil contaminated with crude oil could be related to the ${ }^{\circ}$ API of the oil in the soil. In south and SE Asia, this might occur in on-shore oil fields, such as those in central Sumatra, or upper Assam state (India). In addition, these correlations could be used to evaluate the biodegradability of sludge in on-shore processing facilities, such as those near Johor Bahru (Malaysia) or in Brunei.

Another possible use of this method would be to determine the potential for biodegradation (or long term fertility problems) of the oily viscous fluids (OVF) produced in the steam flooding operations for the extraction of heavy oil, such as those in Alberta (Canada), Venezuela, or Sumatra (Indonesia), (Mai \& Kantzas, 2009; Souraki et al., 2012, 2013; Arfie et al., 2005). These residues are typically composed of a mixture of heavy oil, sand, and water emulsions. The ecological treatment of these kinds of wastes is very problematical in production and processing areas (Arfie et al., 2005). Previous knowledge about the kind of petroleum left in the residue (as opposed to the oil in the reservoir) would be useful to develop treatment strategies that have better logistics or costs benefits.

\section{Conclusion}

The novel method developed in this study provides a simple but reliable analytical tool for the environmental characterization of crude oil in soil, something that was not possible with previously existing methods. Comparing this novel method for ${ }^{\circ} \mathrm{API}$ determination by dilution-extrapolation with the conventional method with hydrometer, there was an excellent correlation $(\mathrm{R}=0.9996)$ and a very low error $(<0.4 \%)$. In quantitative terms, these methods are practically equivalent. However, with the dilution-extrapolation method it is feasible to use very small volumes of oil $(<10 \mathrm{ml})$ facilitating its application to soils with low hydrocarbon concentrations (0.1-1.0\%). Likewise, it is a practical method for the determination of API gravity in heavy and extra-heavy oils, commonly found in soils contaminated by residual hydrocarbons. Thus, the ${ }^{\circ}$ API of oil in contaminated soil can 
be easily determined by recovering small amounts of petroleum from soil using solvent extraction procedures (EPA, 1996), and then applying the dilution-extrapolation method on the recovered oil. For these reasons, it is recommended as a viable alternative for the determination of API gravity in hydrocarbon contaminated soils, and a useful tool for the characterization of contaminated sites, with relevance to the biodegradability of the oil in the soil, and the potential to cause long term fertility problems.

\section{Acknowledgements}

We would like to acknowledge the Consejo Nacional de Ciencia y Tecnología (National Council of Science and Technology, Mexico) and the Government of Tabasco State for financing this research project, Fomix 2009-04, TAB-2009-C18-121493.

\section{References}

Adams, R., Álvarez-Ovando, A. L., Escalante-Espinosa, E., \& Gutiérrez-Rojas, M. (2006). Dose-Response relationship of organisms in soil with heavily weathered hydrocarbons and changes in fertility parameters. 13th International Petroleum Environmental Conference (pp. 1-7), San Antonio, Texas. Retrieved from http://ipec.utulsa.edu/Conf2006/Papers/Adams_37.pdf

Adams, R., \& Morales-García, F. (2008). Concentración residual de hidrocarburos en suelo del trópico: Parte I. Consideraciones para la salud publica y protección al ganado. Interciencia, 33(7), 476-482. Retrieved from http://www.interciencia.org/v33_07/476.pdf

Adams, R., Zavala-Cruz, J., \& Morales-García, F. (2008). Concentración residual de hidrocarburos en suelo del trópico: Parte II. - Afectación a la fertilidad y su recuperación. Interciencia, 33(7), 483-489. Retrieved from http://www.interciencia.org/v33_07/483.pdf

American Society for Testing and Materials International. (2002). ASTM D369-84(2002) Standard test method for specific gravity of creosote fractions and residue. Pennsylvania: West Conshohocken.

American Society for Testing and Materials International. (2006). ASTM D287-92(2006) Standard test method for API gravity of crude petroleum and petroleum products (hydrometer method). West Conshohocken, Pennsylvania.

American Society for Testing and Materials International. (2008). ASTM D6822-02(2008) Standard test method for density, relative density, and API gravity of crude petroleum and liquid petroleum products by thermohydrometer method. Pennsylvania: West Conshohocken.

Ancheyta, J., Centeno, G., Sánchez-Reyna, G., \& Nájera, A. (2011). Cálculo de viscosidad de petróleo mediante real de mezclado con parámetros de interacción binaria. LI Convención Nacional - Instituto Mexicano de Ingenieros Químicos A.C., 20-21 Octubre; Puebla, México. Sesión JM-2-3. Retrieved from http://imiq.com.mx/convencion/web/SESSIONES/JM-3-2.pdf

Arfie, M., Marika, E., Purbodiningrat, E. S., \& Wooda, H. A. (2005). Implementation of slurry fracture injection technology for E\&P wastes at Duri oilfield. SPE Asia Pacific Health, Safety and Environment Conference and Exhibition, Kuala Lumpur, Malaysia, 19-20 September 2005. Paper: SPE 96543-PP. Retrived from http://www.terralog.com/article/SPE-96543-PP.pdf\#zoom=130\%25

Bakhtiari, A. M., Zakaria, M. P., Yaziz, M. I., Lajis, M. N. Hj, \& Bi, X. (2009). Polycyclic aromatic hydrocarbons and $n$-alkanes in suspended particulate matter and sediments from the Langat River, Penisular Malaysia. EnvironmentAsia, 2, 1-10.

Chevron Corporation. (2011). Chevron Crude Oil Marketing/Far Eastern Crudes - Whole Crude Properties. Retrieved from http://crudemarketing.chevron.com/crude/far_eastern

Edwards, D. A., Andriot, M. D., Amoruso, M. A., Tummey, A. C., \& Bevan, C. J. (1995). Development of fraction specific reference doses (RfDs) and refernce concentrations (RfCs) for total petroleum hydrocarbons (TPH), vol. 4. The Association of Environmental Health and Sciences. Retrieved from http://library.wur.nl/WebQuery/clc/1658752

Eisman, M. P., Landon-Arnold, S., \& Swindoll, C. M. (1991). Determination of petroleum hydrocarbon toxicity with Microtox®. Bulletin of Environmental Contamination and Toxicology, 47, 811-816. http://dx.doi.org/10.1007/BF01689508

Infante, C. (2001). Biorestauración de áreas impactadas por crudo por medio de Intebios ${ }^{\circledR}$ y Biorize ${ }^{\circledR}$. Interciencia, 26(10), 504-507. Retrieved from http://www.interciencia.org/v26_10/index.html 
Litvina, M., Todoruk, T. R., \& Langford, C. H. (2003). Composition and structure of agents responsible for development of water repellency in soils following oil contamination. Environmental Science and Technology, 37, 2883-2888. http://dx.doi.org/10.1021/es0262961

Mai, A., \& Kantzas, A. (2009). Heavy oil waterflooding: effects of flow rate and oil viscosity. J. Can. Pet. Technol, 48(3), 42-51.

McMillen, S., Smart, R., \& Bernier, R. (2002). Biotreating E \& P wastes: lessons learned from 1992-2002. 9th International Petroleum Environmental Conference, Albuquerque, New Mexico; pp. 1-14. Retrieved from http://ipec.utulsa.edu/Conf2002/mcmillen_smart_bernier_122.pdf

Osuji, L. C., \& Ezebuiro, P. E. (2006). Hydrocarbon contamination of a typical mangrove floor in Niger Delta, Nigeria. International Journal of Environmental Science and Technology, 3(3), 313-320. Retrieved from http://www.ijest.org/?_action=aricleInfo\&article $=133$

Pemex Refinación. (2010). Diccionario de términos de PEMEX Refinación. México D. F. Retrieved from $\mathrm{http} / / / w w w . i t e k . c o m . m x / I N D U S T R I A / D I C C I O N A R I O \% 20 P E M E X . p d f$

Safari, M., Zakaria, M. P., Mohamed, Che Abd R., Lajis, N. Hj., Chandru, K, Bahry, P. S., ... Anita, S. (2010). The history of petroleum pollution in Malaysia; urgent need for integrated prevention approach. EnvironmentAsia, 3(special issue), 131-142.

Sakari, M., Zakaria, M. P., Lajis, N., Mohamed, C. A. R., Shahpoury, P., Anita, S., \& Chandru, K. (2008). Characterization, distribution, sources and origins of aliphatic hydrocarbons from surface sediments of Prai Straits, Penang, Malaysia: A widespread anthropogenic input. EnvironmentAsia, 1(2), 1-14.

Souraki, Y., Ashrafi, M., Karimaiel, H., \& Torsaeterl, O. (2012). Experimental analyses of Athabasca bitumen properties and field scale numerical simulation study of effective parameters on SAGD Performance. Energy and Environment Research, 2(1), 140-156. http://dx.doi.org/ 10.5539/eer.v2n1p140

Souraki, Y., Ashrafi, M., \& Torsaeterl, O. (2013). A comparative field-scale simulation study on feasibility of SAGD and ES-SAGD processes in naturally fractured bitumen reservoirs. Energy and Environment Research, 3(1), 49-62. http://dx.doi.org/10.5539/eer.v3n1p49

Trujillo-Narcía, A., Rivera-Cruz, M. d C., Lagunes-Espinoza, L. d C., Palma-López, D. J., Soto-Sánchez, S., \& Ramírez-Valverde, G. (2012). Efecto de la restauración de un fluvisol contaminado con petróleo crudo. Revista Internacional de Contaminación Ambiental, 28(4), 361-374. Retrieved from http://www.revistas.unam.mx/index.php/rica/aricle/view/25347

Udoetok, I. A., \& Osuji, L. C. (2008). Gas chromatographic fingerprinting of crude oil from Idu-Ekpeye oil spillage site in Niger-delta, Nigeria. Environmental Monitoring and Assessment, 141, 359-364. http://dx.doi.org/10.1007/ s10661-007-9902-0

United Estates Environmental Protection Agency. (1996). Method 3540C. Soxhlet extraction. SW-846 Manual. Washington, DC: Government Printing Office. Retrieved from http://www.epa.gov/osw/hazard/testmethods/sw846/pdfs/3540c.pdf

Zakaria, M. P., Takada, H., Kumata, H., Nakada, N., Ohno, K., \& Mihoko, Y. (2002). Distribution of Polycyclic Aromatic Hydrocarbons (PAHs) in rivers and estuaries in Malaysia: widespread input of petrogenic hydrocarbons. Environmental Science and Technology, 36, 1907-18. http://dx.doi.org/10.1021/es011278+

Zalik, A. (2010). Volatilidad y mediación en diferentes campos petroleros: las arenas bituminosas y la delta de Niger como lugares de controversia. Revista Umbrales Ciencias Sociales, 20, 307-334. Retrieved from http://www.revistasbolivianas.org.bo/pdf/umbr/n20/n20n20a11.pdf 